\title{
An introduction to the Southland Region
}

JON NEWSON

PO Box 67, Otautau
Keywords: beef, climate, dairy, forestry, land use, sheep, soils, Southland

The $22^{\text {nd }}$ and $40^{\text {th }}$ Grassland Association conferences were held in Invercargill in 1960 and 1978, respectively. The 1978 conference was nearly cancelled as it just followed the massive flooding in Southland that October.

In a farmer paper presented by Mr G.A. McDonald of Brydone, it is of interest that he was sowing lucerne on 5.5 ha of his property to protect from the summer dry. It makes interesting reading how the climate has changed since 1978.

In a recent NIWA publication, this climate shift is described as the Interdecadel Pacific Oscillation. Previous shifts occurred in 1925, 1947 and 1977. Interestingly, NIWA is suggesting this 20-30 year oscillation may be due to switch again. The previous 1977 shift brought wetter and cloudier weather as more anticyclones occurred north of the country. It is interesting to speculate that many areas, previously perceived as dry, may once again become dry. This will have interesting repercussions because of the recent spread of dairying and the increasing land intensification.

\section{The region}

The Southland region covers an area of approximately 2.3 million ha (7840 square miles). The Southland region stretches from Brothers Point in the east to Awarua Point in the West. It covers Fiordland and Stewart Island (known to the local Maori as Murihiku).

Local government bodies in the region include The Southland Regional Council, Southland District Council, Invercargill City Council and Gore District Council. The Department of Conservation administers over $53 \%$ of the total land area of the region.

In the period immediately prior to European settlement, Southland's plains were covered by forest, scrub, tussock and wetland, depending upon climatic conditions and topography.

In the 1840s and 1850s, farmers settled around Invercargill, with the first wool shipped from Invercargill in 1857 . By the end of 1859 , nearly all the suitable areas of the region were occupied by
European farmers, with development occurring adjacent to the region's waterways. In 1859 when the Invercargill Pastoral District was formed, the population of the region had risen from 858 the year before to 1343 , and was increasing. Southland's provincial boundaries were established in 1861.

There are four major rivers within the region - the Mataura, Oreti, Aparima and Waiau. Their catchments are 5360, 3510, 1375, and 8060 square kilometres, respectively.

\section{Annual Rainfall Southland Region}

$\begin{array}{lc}\text { Location } & \text { Annual rainfall (mm) } \\ \text { Milford } & 6267 \\ \text { Manapouri } & 1180 \\ \text { Athol } & 827 \\ \text { Gore } & 836 \\ \text { Tuatapere } & 1178 \\ \text { Riverton } & 1102 \\ \text { Invercargill } & 1042 \\ \text { Bluff } & 994 \\ \text { Oban (Stewart Island) } & 1470\end{array}$

Westerly winds bring plentiful rainfall to the region and with the blocking Fiordland mountains, less rain falls further inland.

\section{Soils of Southland}

The soils of the region were mapped at 1:253 440 scale by the New Zealand Soil Bureau in 1968. At present, Topoclimate South is remapping the region's soil resource and progressively making the maps available. This is at a farm or even at a paddock scale and is seeing reclassification of some areas to new soil types.

The soils are primarily southern-yellow-brown earths near the coast and yellow-grey earths further inland. Volcanic loamy soils are found in the Takitimu and Te Anau basin areas, being brown-granular loams and yellow-brown loams respectively. Significant areas of peat or organic soils can be found south-east of Invercargill on the coastal belt.

Using the old Land Use Capability criteria, the following total soil areas are found in these classes in the region: 
Table 1 Livestock changes in Southland from 1945 to 1981.

\begin{tabular}{cccccc}
\hline Year & $\begin{array}{c}\text { Number of cattle } \\
(000)\end{array}$ & $\begin{array}{c}\text { Number of sheep } \\
(000)\end{array}$ & $\begin{array}{c}\text { Number of dairy animals } \\
(000)\end{array}$ & $\begin{array}{c}\text { Total } \\
(000)\end{array}$ & $\begin{array}{c}\text { New Zealand Total } \\
(000)\end{array}$ \\
\hline 1945 & 154 & 3367 & 51.6 & 43945 & 65767 \\
1952 & 57 & 3012 & 37.5 & 3541 & 67582 \\
1965 & 159 & 7112 & 38.7 & 8057 & 99661 \\
1971 & 266 & 8538 & 17.2 & 9702 & 96418 \\
1981 & 207 & 8826 & 24.4 & 9847 & 113714 \\
\hline
\end{tabular}

$$
\begin{array}{ll}
\text { LUC =1 } & \begin{array}{l}
1094 \text { ha } \\
\text { e.g., Mataura-Tuatapere soils }
\end{array} \\
\text { LUC = } 2 & \begin{array}{l}
171400 \text { ha } \\
\text { e.g., Makarewa, Waikiwi, Crookston }
\end{array} \\
\text { LUC = } 386900 \text { ha } & \begin{array}{l}
386.9 \\
\text { e.g., Dipton, Aparima, Drummond }
\end{array}
\end{array}
$$

There are various sources of land use recommendations for soil types in the region.

\section{Land use}

In recent times, one of the more high profile land use changes has been the increasing area of dairying. The tables show a history of land use change which illustrates that land use has been changing for a long time, oscillating from one sector to another as infrastructure and relative economics change. As you can see, the impact of the wool boom in the early 1950s was to drive up sheep numbers from 3 million in 1952 to 7.1 million in 1965 (Tables 1 and 2). As a consequence, there was a decline in dairy cattle from 51000 in 1945 to a low of 24000 in 1980 . Similarly, you can see the changes in goat numbers in the late 1980s as cashmere and mohair prices boomed. Interesting is the dramatic but lower profile increase in deer numbers during the 1990s with high venison and velvet prices.

Government policies have also had a significant impact on land development, and as a consequence on sheep and beef numbers, in the late 1970s and early 1980s.

In the 1990s we have seen processing plants rationalised to meet the reducing kill and this is now primarily done at Lorneville and Mataura freezing works with several smaller plants at Morton Mains and Charlton. The dairy industry also saw major rationalisation of processing plants to eventually a single plant in the 1980s to service all of Southland's milk. The recent expansion has seen several dramatic increases in processing capacity with further expansion in processing expected.

This increasing farm diversification is seeing more targeted land use and a more resilient local economy develop without dependence on a single farm production system.
Table 2 Stock numbers in Southland by year from 1975 to 1999 (x1000 s.u.).

\begin{tabular}{cccccc}
\hline Year & Beef & Dairy & Deer & Goats & Sheep \\
\hline 1975 & 301 & 31 & & & 2541 \\
1980 & 193 & 24 & 19 & 4 & 6959 \\
1985 & 178 & 31 & 44 & 13 & 8837 \\
1990 & 187 & 38 & 124 & 73 & 8932 \\
1991 & 181 & 44 & 150 & 45 & 8454 \\
1992 & 172 & 53 & 160 & 26 & 8041 \\
1993 & 175 & 71 & 162 & 18 & 7807 \\
1994 & 203 & 114 & 185 & 15 & 7851 \\
1995 & 214 & 126 & 186 & - & 7688 \\
1996 & 204 & 138 & 191 & 10 & 7457 \\
1999 & 230 & 233 & 393 & 7 & 6738 \\
\hline
\end{tabular}

As overall stock numbers increased, fertiliser use increased which necessitated the commissioning of the SouthFert superphosphate works at Awarua south of Invercargill in 1958. Output peaked at 324000 tonnes of product in 1980.

\section{Forestry}

There have been major changes in the forestry resource in terms of planting activity and species mix. Over the last 10 years, a $103 \%$ increase in total plantation area has occurred. Also, the proportion of hardwood and Douglas Fir is now $32 \%$ of the species planted annually (Table 3). Companies are now targeting certain areas for planting, for example in recent times, 14 farms in the Catlins, SE Southland area have been planted out.

Table 3 Changes in forestry in Southland since 1991.

\begin{tabular}{lcccc}
\hline Year & $\begin{array}{c}\text { Pinus } \\
\text { radiata }\end{array}$ & $\begin{array}{c}\text { Douglas } \\
\text { Fir }\end{array}$ & Hardwoods & Total \\
\hline 1991 & 28843 & 2682 & 2322 & 35452 \\
1996 & 46000 & 6710 & 8191 & 62814 \\
1999 & 47084 & 12610 & 10982 & 72128 \\
$\%$ increase & 63 & 370 & 372 & 103 \\
$\%$ total plantings & 65 & 17 & 15 & \\
\hline
\end{tabular}

So forestry has seen a change from harder hill plantings to more developed land conversion and this has competed for property sales against retention as sheep and beef properties. 
The other change, as plantations are maturing, has been the increase in infrastructure with various new mills and a large MDF plant at Mataura, however this increased processing capacity is likely to be challenged as the harvestable resource continues to increase.

\section{Floriculture}

Increasing interest in this sector has come from local bodies who see it as a labour-intensive, high-input system to boost regional employment, as well as from farmers looking for high-value, small-holding enterprises. Several large bulb operations exist with increasing areas of other crops such as peony roses, gentians, hydrangeas and green foliage. Returns from this sector in the region have increased from $\$ 300000$ in 1991 to $\$ 5.2$ million in 1998 , and full-time employment has increased from 36 to 352 people in the same period. 
